\title{
The role of the speech therapist in visual impairments: perceptions of professionals from a rehabilitation center
} Pedro Henrique Silva Carvalho' ${ }^{1}$
https://orcid. org/0000-0002-1639-4361

Ana Cláudia Fernandes ${ }^{1}$ https://orcid.org/0000-0002-4091-3555

Rita de Cassia letto Montilha ${ }^{1}$

https://orcid.org/0000-0003-3741-0006

Universidade Estadual de Campinas, Campinas, São Paulo, Brasil.

Research support source: Fundação de
Amparo a Pesquisa do Estado de São Paulo - FAPESP

Conflict of interests: Nonexistent

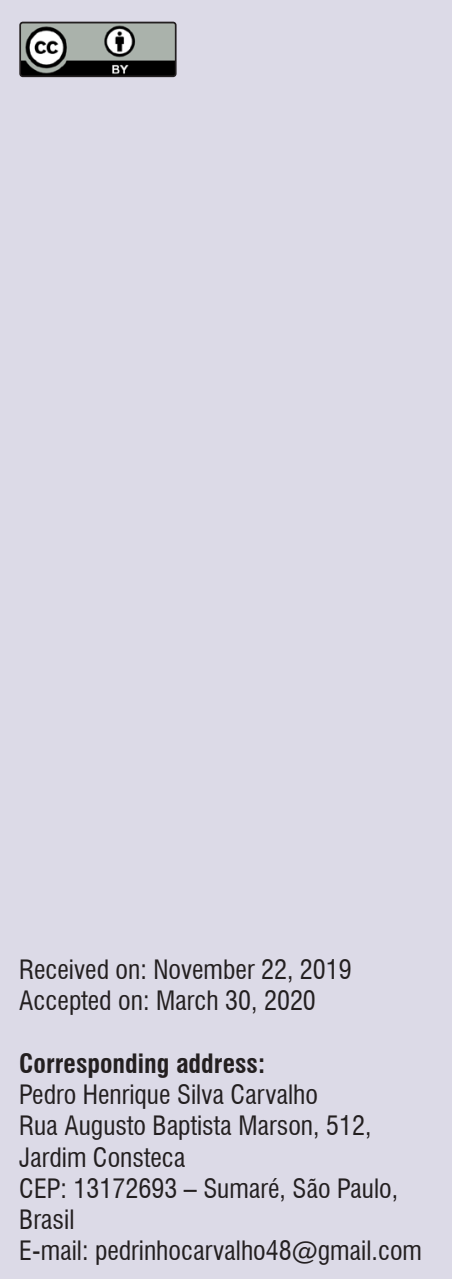

\section{ABSTRACT}

Objective: to know the perception of professionals from a specialized center in habilitation and rehabilitation, regarding the performance of speech therapists working with people presented with visual impairments, in an interdisciplinary team context.

Methods: a qualitative research in which the content analysis was chosen, so as to allow data to be presented in analysis categories.

Results: 11 professionals participated in the research, including psychologists (2), a speech therapist (1), a physiotherapist (1), an ophthalmologist (1), a computer science teacher (1), a pedagogue specialized in Braille (1), a social worker (1), occupational therapists (2), and an orientation and mobility teacher (1). From the analysis of the data, three thematic categories were developed: A. Speech therapy and the development of functions of the stomatognathic system; B. Interfaces between speech therapy and education in the development of reading and writing skills, in cases of people with visual impairments; C. Speech therapy as a promoter of the development of communicative skills, language, interaction, and interpersonal relationships for people with visual impairments.

Conclusion: the research participants considered the speech therapy work as paramount for the rehabilitation of people with visual impairments, and highlighted the fields of activity aimed at developing the functions of the stomatognathic system and working with oral and written language.

Keywords: Rehabilitation; Vision Disorders; Health Services for Persons with Disabilities; Speech, Language, and Hearing Sciences 


\section{INTRODUCTION}

Vision is responsible for providing most of the information that human beings receive from the environment surrounding them, which allows them to know this environment and interact with it and with other individuals, through verbal or nonverbal language ${ }^{1,2}$. In this sense, visual impairments $(\mathrm{VI})$, whether congenital or acquired, cause important impacts, both on the life of affected individuals and their family members. These impacts may be of an economic nature, since, in the case of acquired $\mathrm{VI}$, for example, individuals often become unable to perform their previously carried out work activities, which forces them looking for another job they can do; and/or of psychosocial nature, since, with the presence of a subject with VI in the family, there are changes in the family dynamics and in the roles played by each family member indeed ${ }^{2}$.

We adopt a definition of $\mathrm{VI}$ according to which a person with this disability is considered someone who has low vision, i.e., visual acuity on the best eye and with the best possible optical correction between 0.3 and 0.05 and/or visual field lower than $60^{\circ}$; or blindness, defined as presence of visual acuity on the best eye and with the best possible optical correction lower than or equal to $0.05^{3}$.

Visual acuity is understood as the quantitative measure of an individual's vision, which is estimated by people's ability in identifying letters or numbers on a standardized eye chart from a specific viewing distance. This chart comprises lines with graphic symbols (optotypes) whose dimensions vary along the lines. Conversely, the concept of visual field can be defined as the area of $180^{\circ}$ seen by an observer when facing a certain point ${ }^{4}$.

According to data from the World Health Organization $(\mathrm{WHO})^{5}, 80 \%$ of causes of $\mathrm{VI}$ are preventable or curable. Among the main ones, we can mention the uncorrected refractive errors (myopia, hyperopia, and astigmatism), the non-operated cataract, and glaucoma.

For mitigating impacts on the life of individuals with $\mathrm{VI}$ and on their family members, processes of habilitation and rehabilitation are essential, the first being usually carried out in cases of congenital $\mathrm{VI}$, and the second, in cases of acquired VI. Such processes are extremely important so that people with $\mathrm{VI}$, or even those with other disabilities, have access to their right to live in society with autonomy, independence, and quality, rights that are guaranteed by the Brazilian Constitution and other regulations such as the Brazilian Law for the Inclusion of Persons with Disabilities (Statute for Persons with Disabilities) [Lei Brasileira de Inclusão da Pessoa com Deficiência - Estatuto da Pessoa com Deficiência] $]^{6}$. Therefore, they aim at promoting the inclusion of people with $\mathrm{VI}$, in such a way they can equally develop as an active subject in the society in which they are part of.

According to the Brazilian legislation ${ }^{6}$, services specialized in habilitation and rehabilitation of people with disabilities must have a multidisciplinary and interdisciplinary team, which, according to Monteiro and Montilha ${ }^{7}$, provides individuals with $\mathrm{VI}$ a comprehensive care to the extent that, in this work condition, relationships between different healthcare professionals become more horizontal.

As part of this team, speech therapists can and must be included, since they integrally work with several disorders related to communication, language (oral and/or written), hearing and balance, voice, as well as stomatognathic functions (suction, chewing, swallowing, breathing, and speech), which subjects with VI can manifest in addition to those concerning orientation and mobility, activities of daily living, and Braille teaching-related (in the case of people diagnosed with blindness) $)^{7,8}$. Nevertheless, there are still few studies in the speech therapy literature whose authors describe the way the work of speech therapists is performed with subjects with VI.

Hence, the perception of professionals working with rehabilitation of people with $\mathrm{VI}$ on the highlighted theme becomes very relevant, since, for being directly involved in the rehabilitation work, these professionals can provide valuable information regarding the speech therapy practice in the care of subjects with VI .

Taking this into account, this study aimed to investigate the perception of professionals from a specialized service in habilitation and rehabilitation regarding the performance of speech therapists working with people with visual impairments in the interdisciplinary team context.

\section{METHODS}

This study is part of a larger research project titled O itinerário da pessoa com deficiência visual nos serviços de saúde e reabilitação em um município da Região Metropolitana de Campinas - SP, Brasil [The itinerary of people with visual impairment in healthcare and rehabilitation services in a municipality in the Metropolitan Region of Campinas - SP, Brazil]. This project was approved by the Research Ethics Committee of the School of Medical Sciences 
- University of Campinas (FCM - Unicamp) under protocol no. CAAE 46001215.7.0000.5404 in 2015, and all participants signed an Informed Consent Form. Data were collected by semi-structured interviews conducted in 2018 with professionals working in the service specialized in ophthalmology and rehabilitation of people with $\mathrm{VI}$ in a city in the countryside of the state of São Paulo. This type of interview is characterized as a script with general topics selected and elaborated in order to have open- and closed-ended questions, i.e., containing questions and possible answers.

To guarantee the reliability of the semi-structured interview script as an instrument for data collection, an exploratory study was carried out, which is a very important research step in order to assist in the preparation of this instrument and to adapt it to the reality conditions? .

This is a qualitative study, in which we analyzed data on the theme of rehabilitation of people with $\mathrm{VI}$ and the performance of speech therapists in the rehabilitation process. Such data are part of the corpus formed by the semi-structured interviews carried out with subjects of the present research.

The qualitative research comprised, as structural terms ${ }^{10}$, the following nouns: experience, lived experience, common sense, and social and/or human action. The first of these terms concerns individuals' understanding of the world around them and their own actions on this world, which is expressed in language. On the other hand, subjective experience is defined as the subjects' personal reflection on their experiences, in such a way even in cases where two people have gone through the same experience, each person's subjective experience will be different. The third noun, common sense, is related to the knowledge acquired through the subjects' experiences and subjective experiences, which guide human beings in their attitudes towards numerous daily situations, in such a way to constitute their beliefs, values, opinions etc. The last of these nouns, social and/or human action, refers to the way subjects and institutions build their own lives based on the reality conditions, in order to transform the world around them.

In addition to nouns, qualitative research has also two verbs among its structural terms, namely: to understand and to interpret ${ }^{10}$. The verb "to understand" must be used in the sense of putting yourself in the place of the speakers, in order to consider their uniqueness as a subject and their collective cultural and historical context. "To interpret," on the other hand, refers to the act of appropriating of what has been understood and "projecting" new possibilities of that understanding.

Therefore, we chose content analysis ${ }^{11}$ as a way of analyzing and interpreting such data, which is defined as:

[...] a set of techniques to analyze the communications with the purpose of obtaining, through systematic and objective description procedures of the content of the messages, indicators (whether or not quantitative ones) that allow the inference of understandings related to the production/reception conditions (inferred variables) of these messages ${ }^{11}$.

In addition, Caregnato and Mutti ${ }^{12}$ emphasize that content analysis can be quantitative, in order to perform statistical calculations concerning the presence frequency of a certain word, sentence, or expression in the analyzed text; or qualitative, in order to verify the presence or absence of certain content characteristics in an excerpt, which is the subject's means of expression.

In our study, answers given by the subjects participating in the research were read, with subsequent identification of the themes that emerged from their statements ("indicators"), and elaboration of the analysis categories ${ }^{11,12}$.

\section{RESULTS}

The results will be presented per category and, in order to protect the identity of the subjects participating in the research, statements will be preceded only by the letter "P" followed by an Arabic numeral from 3 to 13.

Eleven (11) subjects participated in this research, including a speech therapist (1), a social worker (1), a physiotherapist (1), a computer science teacher (1), a pedagogue specialized in Braille (1), an orientation and mobility teacher (1), occupational therapists (2), psychologists (2), and an ophthalmologist (1).

From the data analysis, we developed three thematic categories:

- Speech therapy and the development of functions of the stomatognathic system;

- Interfaces between speech therapy and education in the development of reading and writing skills in cases of people with visual impairments;

- Speech therapy as promoter of the development of communicative skills, language, interaction, and interpersonal relationships for people with VI. 


\section{CATEGORY A: Speech therapy and the development of functions of the stomatognathic system}

In this category, we observed that professionals addressed the issue of food introduction as a work developed by speech therapists with people with VI, which influences the development of the stomatognathic functions of sucking, chewing, swallowing, and speaking. In addition, they highlighted the importance of guidelines for stimulating these functions at home, which should be clarified to family members of these subjects with disabilities, as we can observe in the data transcribed next:

P12: "I think it's very important, because we have a lot of patients with difficulties in swallowing, speaking..."

P9: "The speech therapist work is very important for this issue of the sound of letters, syllables, this articulation that must be performed, exercises that must be done... Because it is visual; how are they [people with $\mathrm{VI}$ ] going to do the exercises in front of the mirror? So there must be a specialized speech therapist to work with this. [...] first with the issue of food introduction, which demands a lot of work, otherwise, there will be damages in the future, it will damage the speech, this whole situation. [...] So, when there's a little kid, she [the speech therapist] calls: "What is the child drinking? Is it a baby bottle? Then bring me the bottle. Show me how you are feeding the child, [how you are using] this baby bottle." So she performs all this very delicate work. Then, she asks: "Today, bring me food." Or, when it doesn't work, there's a kitchen here, you know... "Oh, I want it like this, like that..." She gives it to the mom, she teaches it, she stimulates it. It's really nice."

P5: "[...] I've already worked with speech therapists specialized in dysphagia, I could see the importance in terms of food, this independence in activities..."

P11: "[...] I don't really know it [...] but I see it like that: the child, due to the disability, has greater difficulty in handling food, in swallowing..."

\section{CATEGORY B - Interfaces between speech therapy and education in the development of reading and writing skills in cases of people with visual impairments}

We perceived that participants of our research strongly emphasized the partnership between speech therapy and pedagogy, considering that the first may help the latter, since it stimulates the development of skills that facilitate the literacy process, as evidenced by the following statements:

P9: "[...] when it comes to the school matter, if there is no effective monitoring of a speech therapist, then we spin our wheels on the issue of literacy, 'cause, for example, there are methods to teach how to read and write, to teach. And here it's good because she [speech therapist at the service] monitors them [children with disabilities] since they are little and keeps doing it so until they are doing well at school, because the school situation is also difficult, you know."

P13: "[...] there is a support work mainly in the area of pedagogy, with children, so that some important concepts for literacy are stimulated [...] thus, always focusing on the development of concepts that can assist in pedagogy, in the literacy process of the person."

P11: "[...] writing itself, written and spoken language. So, this work done with the computer, I think she [speech therapist at the service] recommended it, you know; then, that with the exchange of letters [...]."

P10: "[...] not that much now, but before we had a large school-age population, and the work was carried out with pedagogy, with reading and writing disorders associated with pedagogy in order to provide greater support, so this school period could be more trouble free..."

\section{CATEGORY C - Speech therapy as a promoter of the development of communicative skills, language, interaction, and interpersonal relationships for people with VI}

Regarding the role of speech therapy as a promoter of the development of communicative skills, professionals mentioned aspects such as the process of language acquisition, speech development - deemed by them as communication -, and the language work 
carried out with subjects with associated impairments, i.e., individuals who, in addition to $\mathrm{VI}$, also have other disorders of sensory, intellectual, or motor nature. We can observe this in the excerpts transcribed next:

P8: "Wow, I think it's very, very important, because, many times, they can't understand the phonemes; it helps a lot in the language acquisition of the child, even of the adult."

P13: "[...] and even with clinical patterns of disabilities, as for language acquisition itself, anyway, as for stimulation; if it is a child, in the stimulation of language acquisition ... [...] and clinical patterns of difficulties even related to speaking, we have cases of deafness associated with visual impairments, or even motor delay. Thus, it's always about working together, right, so it's really important."

P5: "I think the work of speech therapists is very important, 'cause there are children who, due to visual impairments, have great difficulty in interacting with other people, they're very isolated in their difficulty in playing; so I think the communication part is somehow limited. So I think it's very important to work on this part of language, communication, expression. Sometimes, we see children who arrived here without any expression, without any communication, and with the assistance of a speech therapist this part was stimulated, that of social interaction, expression, they became more communicative, playing has become more meaningful..."

P4: "It is important indeed, like, I am working with the speech therapist an alternative communication along with a child who has low vision and myelomeningocele, and this cognitive development is very regressed, in such a way we are working on an alternative communication with him. [...] here I see this language issue, and she [speech therapist at the service] also works with it."

P3: Here is the thing, usually, many of the cases, specially involving children, they arrive at the service, not always the, hum, the... the patient has only a visual impairment. Sometimes they are syndromic patients, so they'll have a visual impairment, a hearing impairment, a motor impairment. Hence, there is... there's need for a multidisciplinary team.

P7: “[...] yeah, because you need to develop speech, right, the more so as for children, and children with [visual] impairments, they cannot see a person speaking, so the speech therapist already works with it, you know."

P6: "[...] people who arrive here have a visual impairment, low vision, or total blindness, they have no vision, so what should we essentially have? Communication. We have to communicate. [...] and interaction is key in communication, you know, that's how I see it [...] speech therapy is paramount, you know. My communication as well, we are also here, interacting, it's part of rehabilitation, there shouldn't be rehabilitation without speech therapy."

From the presentation of these categories, we could compare the statements of the subjects participating in the research with the existing scientific literature in the areas of speech therapy and VI, as we shall detail in the following discussion.

\section{DISCUSSION}

The content analysis method allowed us to know, by the categorization of data, what knowledge the professionals of the specialized service in habilitation and rehabilitation of people with VI have about the performance of the speech therapist working with these individuals. In a similar study ${ }^{7}$, researchers used a selfadministered questionnaire, and semi-structured interviews were carried out with professionals working at a research and rehabilitation center in the countryside of the state of São Paulo; the authors found that most of the research participants stated that the speech therapist's main fields of activity in the rehabilitation of subjects with $\mathrm{VI}$ are orofacial motricity, development of speech and language, as well as the improvement of reading and writing skills, which is in line with the categories outlined in our study. However, authors of the aforementioned research ${ }^{7}$ did not proceed with the categorization of data, and neither addressed the professionals' statements as we did in our study.

Regarding the theme introduced in Category A speech therapy and the development of functions of the stomatognathic system -, we observed there are few studies in the speech therapy literature whose authors specifically address such theme. Authors of some studies $^{7,13}$ defend the existence of a postural imbalance in people with $\mathrm{VI}$, which occurs due to the lack of visual feedback, negatively influencing the anatomy of the stomatognathic system and, consequently, the functions performed by it. Other researchers ${ }^{14-16}$ corroborate this argument, as they present a strict relationship 
between postural alignment and the anatomy of the stomatognathic system, in such a way that poor cervical posture has been associated with the presence of temporomandibular disorder (TMD) as well as with cases of malocclusion.

Furthermore, it is noteworthy the importance of vision for learning oral-related and body posture behaviors that must be adopted during feeding situations, such as closed lips, erect spine, head aligned to the spine etc., considering these are visually observed habits. These postures can be developed through proprioceptive stimulation, enabling subjects with VI to have a global perception of their own body and to be attentive to body behaviors they should adopt in a feeding situation ${ }^{13}$. Professional P9 mentions the importance of this work using other sensory pathways than vision for the development of stomatognathic functions in people with VI, when stating "[...] Because it is visual; how are they [people with $\mathrm{VI}$ ] going to do the exercises in front of the mirror? So there must be a specialized speech therapist to work on this." Nevertheless, professionals did not report the sensory pathway by which this stimulation can be provided; but, for the professional practice, the work of stimulation of remaining senses is paramount.

In addition to food introduction and the very stomatognathic functions, one of the professionals (P9) emphasizes the importance of family guidance on the part of speech therapists, in order to provide the family with practical information with which they can work, along with this professional, on the early stimulation of sensory pathways other than vision, which can contribute for individuals with VI to develop body awareness. Researchers ${ }^{8}$ defend that the work of the speech therapist, and even of healthcare professionals in general, with the family is extremely important for the process of habilitation and rehabilitation of people with $\mathrm{VI}$, since it is the first group with which these people interact and develop their interpersonal relationships.

As for the work of speech therapists on reading and writing skills of people with $\mathrm{Vl}$, addressed by Category $B$, we observed, as aforementioned, that most professionals emphasize the partnership relationship between speech therapists and pedagogues in the rehabilitation process. Authors ${ }^{17}$ state that the relationship between these professionals, in the school context, provides numerous benefits, since speech therapists can transmit to the teacher their knowledge about acquisition and development of oral and written language, as well as the existing relationships between them, thus, enabling the teacher to identify those individuals who need speech therapy in order to develop their potential. In the specific case of people with $\mathrm{VI}$, for this population to be properly included in the regular school, rehabilitation professionals must work with educators, in order to provide them with teaching/learning strategies they can use in their daily lives at the school for meeting the educational needs of these students ${ }^{18}$. In this sense, speech therapists, together with the rehabilitation team, can suggest changes in the school environment aiming at improving the learning conditions of students with $\mathrm{VI}$, such as: changing the students' seats in the classroom so they can be closer to the board and, thus, they can better see and understand the content being taught by hearing; thinking about ways to control the lighting in the classroom; checking if the dimensions of the used letters are adequate to the students' visual characteristics etc. It is noteworthy that all these changes must be discussed in dialogues and/or by exchanging constant reports with the teacher and students, in such a way they meet the real needs of students and facilitate their learning process.

Despite authors of the aforementioned studies referring to the school context, benefits of such partnership can be extrapolated to the context of rehabilitation, since speech therapists and pedagogues specialized in special education, and technical teachers in computer science, can share knowledge and discuss the conduct of each one when dealing with individuals with VI, either low vision or blindness.

In order to work on the development of the reading and writing potential of people with VI within the context of rehabilitation, speech therapists must be able to propose other ways of working with these skills than those used with normally seeing subjects, which presupposes knowledge, on the part of these professionals, of existing resources of optical and non-optical assistive technology (AT) for performing this work ${ }^{19,20}$. Such statement corroborates what was reported by professional P11 when mentioning the "work done with the computer" developed by the speech therapist at the service.

Another professionals' perception regarding the speech and language work with reading and writing skills in the case of people with $\mathrm{VI}$, is the stimulation of abilities that favor the literacy process such as the grapheme/phoneme relationship, phonological processing, among others. However, reading and writing should be developed by speech therapists in order to (re)signify these practices in the lives of 
subjects with $\mathrm{Vl}$, in such a way to consider the social contexts in which reading and writing are useful and important $^{21,22}$. To do so, they can work with themes of interest to the subject, in which reading and writing can be inserted. Of course, we are not disregarding the importance of improving the skills previously mentioned, but the aim is to expand the possibilities of approaches that can be used by speech therapists in the clinical practice concerning reading and writing skills of individuals with VI.

Conversely, regarding Category $\mathrm{C}$, in relation to communication skills, we observed that, as already highlighted in the results, the speech therapy work was addressed as being even more essential in cases of individuals with associated disabilities for developing their communication skills. To contribute to language acquisition and development processes of individuals with associated disabilities, such as those with deafblindness, for example, speech therapists must use different communication/interaction techniques, such as the Brazilian Tactile Sign Language (tactile Libras), the Braille system, the Tadoma method (a technique for identifying phonemes of the language by manually touching the orofacial region), speaking with a higher degree of articulation, in the case of hearing and/or visual residue, among others ${ }^{23}$.

The adopted communication techniques depend on many factors in addition to the presence or absence of sensory residues, since characteristics, such as the period when there was loss of each sensory pathway, presence or not of cognitive or motor impairments, the socioeconomic context of individuals etc., directly influence this decision ${ }^{23}$. Moreover, speech therapists must propose significant activities for promoting the stimulation of interaction and joint attention between speakers ${ }^{24}$. Joint attention is understood as the sharing of the attentional focus between two individuals on the same event and/or object, which is developed in human beings after 9 months of life ${ }^{25}$.

Concerning the performance of speech therapists in the case of associated disabilities, we recommend the need for these professionals to have knowledge of the functioning of the visual system - not only for working with issues concerning the visual impairment, but rather because this impairment is accompanied by other motor and/or sensory disabilities of which, traditionally, speech therapists have more knowledge. Nevertheless, professionals participating in our study reported the importance of speech therapists even in cases where subjects only have VI (blindness or low vision). Regarding the attendance of cases of this nature, in relation to language and communication, in the transcribed excerpts we observed that professionals consider the speech therapist as a professional whose practice favors the interactions of these subjects with people around them, as evidenced by the report of professional P5, who observes improvement in interaction after the speech therapist assistance in consultations carried out at the service where the research was conducted.

Emphasizing the importance of this practice, researchers ${ }^{7,26}$ mention that, due to the shock experienced by parents/relatives with the birth of a child with disability, and the child's usually passive condition in the face of looks and stimuli to communication of a visual nature, interactive experiences of subjects with $\mathrm{VI}$ are often limited, which can negatively influence the language development process. The statement of professional $\mathrm{P} 5$, however, associates interaction difficulties observed in subjects with VI with the visual impairment itself, and does not consider aspects related to the family environment highlighted in the literature.

Another issue concerning interaction consists in nonverbal aspects present in a dialogue, such as looking at the speakers while they are speaking, in such a way to guaranteeing them the attentional focus is kept throughout the conversation, as emphasized by professional P7 when saying that subjects with VI "cannot see a person speaking." Speech therapists are aware that this behavior, which is so natural among seeing people, is not obvious and neither intuitive in the case of subjects with $\mathrm{VI}$ and, therefore, it is something that can also be developed in speech therapy activities ${ }^{7}$.

It is worth noting that one of the professionals (P8) highlights a language-related aspect, the phonological level, which, according to this research participant, may be altered in subjects with VI, since they "can't understand the phonemes." According to a study ${ }^{26}$ carried out on 20 children with low vision, in the age group of 6-9 years, and attended at a specialized rehabilitation center in Salvador - state of Bahia, Brazil, children with low vision may have delayed phonological development. However, considering the very limited number of subjects in our research, in addition to the individuality and context of each individual, with many possible social and cultural variables, we cannot consider this result as expected for most people with VI .

Despite emphasizing the impact of the news about a person with disability in the family, we must consider aspects, such as socioeconomic level and specific 
characteristics of the family environment in which each subject lives, and such were disregarded. These factors, according to the literature ${ }^{27}$, directly influence the process of language acquisition and development as a whole and, therefore, the phonological development. In a sociocultural perspective of language development, language acquisition occurs through interactions between children and adults; therefore, aspects concerning the environment where these children are going to develop are relevant.

Moreover, also concerning the aforementioned study ${ }^{26}$, the protocol used for the assessment should be considered, which consisted in a set of images about which individuals have to say a corresponding word. Although these images have been enlarged, the visual acuity of each child participating in the study was disregarded, in such a way the authors could not know the best dimension of the pictures to be used with each subject.

Thus, as highlighted, it is key for speech therapists to be specialized, to know the peculiarities of visual impairments and their possibilities, since, as reported by all participants, the field of speech therapy complements the work of rehabilitation of people with VI. Furthermore, within the interdisciplinary team context, their work favors not only the development of users of the rehabilitation center, but also the team's knowledge of speech therapy.

\section{CONCLUSIONS}

Our study allowed us to know the perceptions of professionals about the work of speech therapy in cases of people with visual impairment. We observed that speech therapy was deemed extremely important in the habilitation and/or rehabilitation process of individuals with this disability. The most highlighted fields of activity in the statements of research participants were the development of the functions of the stomatognathic system and the work with language, both in its written modality and in relation to communicative skills in interpersonal relationships.

Moreover, we highlight that developing more studies on the field is relevant, studies whose authors report experiences of the speech therapists' performance with visually impaired people, aiming at detailing the way these professionals can work in these cases and, hence, contributing to broadening the field of speech therapy and providing theoretical bases for the clinical practice in the field of VI.

\section{ACKNOWLEDGEMENTS}

We thank the Fundaçao de Amparo a Pesquisa do Estado de São Paulo (FAPESP) for funding our research.

\section{REFERENCES}

1. Gaete MIL, Lira RPC, Moraes LFL, Vasconcelos MSL, Oliveira CV. Associação entre a necessidade de prescrição de correção óptica e outras doenças oculares em crianças na idade escolar. Arq. Bras. Oftalmol. [periódico na internet]. 2007 [acesso em 24 jul 2019]; 70(6): [aproximadamente 4 p.]. Disponível em: http://www.scielo.br/pdf/abo/v70n6/ a12v70n6.pdf

2. Oliveira CAS, Hisatomi KS, Leite CP, Schellini AS, Padovani CR, Padovani CRP. Erros de refração como causas de baixa visual em crianças da rede de escolas públicas da regional de Botucatu - SP. Arq. Bras. Oftalmol. [periódico na internet]. 2009 [acesso em 03 dez 2018]; 72(2): [aproximadamente 5 p.]. Disponível em: http://www.scielo.br/scielo.php?script $=$ sci_ arttext\&pid=S0004-27492009000200012

3. Brasil. Decreto o 5.296 de 2 de dezembro de 2004. Regulamenta as Leis $n^{\circ s} 10.048$, de 8 de novembro de 2000, que dá prioridade de atendimento às pessoas que especifica, e 10.098, de 19 de dezembro de 2000, que estabelece normas gerais e critérios básicos para a promoção da acessibilidade das pessoas portadoras de deficiência ou com mobilidade reduzida, e dá outras providências [internet]. Diário Oficial da República Federativa do Brasil. 2004 dez. 02 [acesso em 2019 jul. 24]. Disponível em: http://www.planalto.gov.br/ ccivil_03/_Ato2004-2006/2004/Decreto/D5296.htm

4. Silva MR. Avaliação terapêutica ocupacional para adolescentes e adultos com deficiência visual baseada na Classificação Internacional de Funcionalidade, Incapacidade e Saúde (CIF) [dissertação] [internet]. Campinas (SP): Universidade Estadual de Campinas; 2016. [acesso em 2017 maio 02]. Disponível em: http://repositorio. unicamp.br/jspui/handle/REPOSIP/321851

5. WHO: World Health Organization. Visual impairment and blindness. [acesso em Jul. 2018]. Disponível em: http://www.who.int/mediacentre/ factsheets/fs282/en/

6. BRASIL. Presidência da república, Subchefia para Assuntos Jurídicos. Lei no 13.146 de 6 de julho 
de 2015. Institui a Lei Brasileira de Inclusão de Pessoa com Deficiência (Estatuto da Pessoa com Deficiência) [internet]. [Diário Oficial da República Federativa do Brasil]. 2015 jul. 7 [acesso em 2019 jul. 24]. Disponível em: http://www.planalto.gov.br/ ccivil_03/_ato2015-2018/2015/lei/l13146.htm

7. Monteiro MMB, Montilha $\mathrm{RCl}$. Intervenção fonoaudiológica e deficiência visual: percepções de profissionais de equipe interdisciplinar. Medicina (Ribeirão Preto) [periódico na internet]. 2010 mar [acesso em 31 mar 2018]; 43(1): [aproximadamente 9 p.]. Disponível em: https:// www.revistas.usp.br/rmrp/article/view/160

8. Fernandes AC, Montilha RCl. The comprehensive evaluation in speech therapy for people with visual impairments: a case report. Rev. CEFAC. [serial on the internet]. 2015 [cited 2018 mar 22]; 17(4): [about 8 p.]. Available from: http://www.scielo.br/pdf/ rcefac/v17n4/en 1982-0216-rcefac-17-04-01362. pdf

9. Piovesan A, Temporini ER. Pesquisa exploratória: procedimento metodológico para o estudo de fatores humanos no campo da saúde pública. Rev. Saúde Pública. 1995;29(4):318-25.

10. Minayo MCS. Qualitative analysis: theory, steps and reliability. Ciênc. saúde coletiva. [serial on the Internet]. 2015 [cited 2019 mar 10]; 17(3): [about 6 p.]. Available from: http://www.scielo.br/pdf/csc/ v17n3/en_v17n3a07.pdf

11. Bardin L. Análise de conteúdo. 4. ed. Lisboa: Editora 70; 2004.

12. Caregnato RCA, Mutti R. Pesquisa qualitativa: análise de discurso versus análise de conteúdo. Texto contexto - enferm. [periódico na internet]. 2006 out/dez [acesso em set 2018]; 15(4): [aproximadamente 6 p.]. [acesso em set 2018]. Disponível em: http://www.scielo.br/pdf/tce/v15n4/ v15n4a17.pdf.

13. Silva PMVA. Deficiência visual e sistema estomatognático: uma relação de importância para a Fonoaudiologia [tese]. Campinas (SP): Universidade Estadual de Campinas; 2018.

14. Cuccia A, Caradonna C. The relationship between the stomatognathic system and body posture. Clinics. 2009;64(1):61-6.

15. Roggia B, Filha VAVS, Correa B, Rossi AG. Posture and body balance of schoolchildren aged 8 to 12 years with and without oral breathing. CoDAS [serial on the internet]. 2016 [cited 2019 jul 15]; 28(4): [about 8 p.]. Available from: http:// www.scielo.br/pdf/codas/v28n4/en_2317-1782codas-2317-178220162015002.pdf

16. Parrilla JMM, Chipombela LCM, Semykina O. La oclusión dentaria en interacción con la postura corporal. Revista Cubana de Estomatología 2014;51(1):15-23.

17. Maranhão PCS, Pinto SMPC, Pedruzzi CM. Fonoaudiologia e educação infantil: uma parceria necessária. Rev. CEFAC. 2009;11(1):59-66.

18. Moura MC, Albuquerque BFO. $O$ trabalho pedagógico desenvolvido pela ASAC (Associação Sorocabana de Atividades para Deficientes Visuais): um estudo de caso. REB. 2014;7(2):157-2.

19. Monteiro MMB, Montilha RCl, Gasparetto MERF. A atenção fonoaudiológica e a linguagem escrita de pessoas com baixa visão: estudo exploratório. Rev. bras. educ. espec. 2011;17(1):121-36.

20. Zerbetto AB, Lopes FFS, Montilha RCl, Gasparetto MERF. Interdisciplinary team performance with students that have low vision due to their diagnosis of Stargardt Disease. Rev. CEFAC. [serial on the Internet]. 2015 [cited 2019 jul 16]; 17(1): [about 9 p.]. Available from: http://www.scielo.br/pdf/rcefac/ v17n1/en_1982-0216-rcefac-17-01-00291.pdf

21. Monteiro MMB, Carvalho KMM. Avaliação da autonomia em atividades de leitura e escrita de idosos com baixa visão em intervenção fonoaudiológica: resultados preliminares. Rev. Geriatr. Gerontol. 2013;16(1):29-40.

22. Mori-de Angelis CCA, Dauden ATBC. Leitura e escrita: uma questão para fonoaudiólogos? In: Dauden ATBC, Mori-de Angelis CC (orgs). Linguagem escrita: tendências e reflexões sobre o trabalho fonoaudiológico. 1 ed. São Paulo: Pancast; 2004. p. 37-64.

23. Villas Boas DC, Ferreira LP, Moura MC, Maia SR. A comunicação de pessoas com surdocegueira e a atuação fonoaudiológica. Distúrb Comun. 2012;24(3):407-14.

24. Villas Boas DC, Ferreira LP, Moura MC, Maia SR, Amaral I. Analysis of interaction and attention processes in a child with multiple desabilities. Audiol., Commun. Res. [serial on the Internet] 2017 [cited 2019 jul 16]; 22: 1718 [about 7 p.]. Available from: http://www.scielo.br/pdf/acr/v22/en_23176431-acr-2317-6431-2016-1718.pdf

25. Tomasello M. atenção conjunta e aprendizagem cultural. In: Tomasello M (org). Origens culturais da aquisição do conhecimento humano. 1 ed. São Paulo: Martins Fontes; 2003. p. 77-129. 
26. Lima AL, Nunes RTDA. Phonological profile of children with low vision from 6 to 9 years old at an institution for the blind in the city of Salvador - BA. Rev. CEFAC. [serial on the internet]. 2015 [cited 2018 dez 9]; 17(5): [about 9 p.]. Available from: http://www.scielo.br/pdf/rcefac/v17n5/en_19820216-rcefac-17-05-01490.pdf

27. Medeiros CS, Salomão NMR. Estratégias de comunicação: interação mãe-criança com deficiência visual e habilidades sociocomunicativas infantis. Rev. Bras. Ed. Esp. 2015;21(4):393-406. 